When Affective Well-being is Empowered:

The Joint Role of Leader-Member Exchange and the Employment Relationship

Mieke Audenaert, Ghent University

Alex Vanderstraeten, Ghent University

Dirk Buyens, Vlerick Business School

In Press at International Journal of Human Resource Management

Mieke Audenaert ${ }^{1}$, Department of HRM and Organizational Behavior, Faculty of Economics and Business Administration, Ghent University, Campus Mercator, Henleykaai 84, 9000 Ghent, Belgium, mieke.audenaert@ugent.be, +32 924329 56; Alex

Vanderstraeten, Department of HRM and Organizational Behavior, Faculty of Economics and Business Administration, Ghent University, Campus Mercator, Henleykaai 84, 9000 Ghent, Belgium, alex.vanderstraeten@ugent.be; Dirk Buyens, Department of HRM and Organizational Behavior, Faculty of Economics and Business Administration, Vlerick Business School \& Ghent University, Reep 1, 9000 Ghent, Belgium, dirk.buyens@vlerick.com

${ }^{1}$ Corresponding author: 


\begin{abstract}
HRM and the leader are often assumed to play a joint role in affecting employee reactions. In a multilevel, time-lagged study, we examined the joint role of the employment relationship and leader-member exchange. We tested whether this joint role is essential to when leadermember exchange leads to affective well-being via psychological empowerment. We build on HRM literature to expect that the relationship of leader-member exchange with psychological empowerment is stronger when the employment relationship is consistent with leader-member exchange quality. Results indicated that psychological empowerment mediates the relationship between leader-member exchange and affective well-being. This mediation is stronger for employees in a mutual investment employment relationship. The findings point at the importance of consistency of resources from the employment relationship and leadermember exchange. Nevertheless, the findings also suggest that resources from leader-member exchange compensate for employment relationships with low resources. Our findings contribute to scholars' understanding of the joint role of HRM systems and leader behaviors.
\end{abstract}

\title{
Keywords
}

Employment relationship, LMX, psychological empowerment, affective well-being, HRM systems, leader behavior 


\section{When Affective Well-being is Empowered: The Joint Role of Leader-Member Exchange and the Employment Relationship}

HRM and the leader are often assumed to play a joint role in affecting employee reactions (Gilbert, De Winne, \& Sels, 2011; Kuvaas \& Dysvik, 2010; Purcell \& Hutchinson, 2007). This study examines the joint role of HRM and the leader by studying the employment relationship and Leader-Member Exchange (LMX). Specifically, we look at when LMX relates to psychological empowerment and affective well-being by studying the employment relationship as a moderator. While LMX quality reflects that leaders differentiate in the extent to which they provide support and hold high expectations from their individual employees

(Henderson, Liden, Glibkowski, \& Chaudhry, 2009), the employment relationship encompasses HRM practices that signal differential support and expectations at the job level.

How much the organization supports job incumbents by giving training, career guidance, material rewards, and how much is expected from them by setting performance goals differs between jobs (Shaw, Dineen, Fang, \& Vellella, 2009; Tsui, Pearce, Porter, \& Tripoli, 1997).

It is well established that high-quality LMX is related to affective well-being (i.e., job satisfaction and emotional exhaustion) (Dulebohn, Bommer, Liden, Brouer, \& Ferris, 2012). Employees with a high-quality LMX relationship get emotional support and enjoy trust from their leader. Consequently, they experience more job satisfaction and less emotional exhaustion (Skakon, Nielsen, Borg, \& Guzman, 2010). In addition to this direct linkage between LMX and affective well-being, mediators are seen as potentially relevant in the LMX-outcomes relationship (Aryee \& Zhen Xiong, 2006; Loi, Mao, \& Ngo, 2009). Based on the motivational underpinnings of psychological empowerment (Spreitzer, 1995; Thomas \& Velthouse, 1990), it has been argued that psychological empowerment explains how LMX and affective wellbeing are related. However, although some previous studies support this mediating role (Aryee \& Zhen Xiong, 2006; Pan, Zhou, \& Zhou, 2010), other research does not (Liden, Wayne, \& 
Sparrowe, 2000). These conflicting findings point at the need for a greater understanding of when LMX is related to affective well-being via psychological empowerment.

\section{Insert Figure 1 about here}

It is our aim to extend the current research by proposing the employment relationship as a moderator in this mediated relationship. Studying the employment relationship would be fruitful because it offers a conceptualization of multiple, distinct HRM approaches (Tsui \& Wu, 2005). This allows a more nuanced study of HRM than a control-commitment continuum (Guest, Paauwe, \& Wright, 2012; Hauff, Alewell, \& Hansen, 2014). Specifically, by introducing the employment relationship as a moderator, it is our aim to further the insights on the joint role of HRM and the leader (Kuvaas \& Dysvik, 2010; Purcell \& Hutchinson, 2007). Pertaining to this joint role, the need for consistency of the signals from HRM and the leader is emphasized in HRM literature (Bowen \& Ostroff, 2004; Liu, Lepak, Takeuchi, \& Sims, 2003). This need for consistency is supported by research about individually perceived HRM and support from the leader (Kuvaas \& Dysvik, 2010). We expect that consistency will also be relevant for the job-level employment relationship and LMX.

As depicted in Figure 1, we study when LMX is related to affective well-being via psychological empowerment by addressing the role of the job-level employment relationship. In accordance with the view that the HRM-performance linkage occurs through different levels of analysis (Nishii \& Wright, 2008), this implies a multilevel model. 


\section{Background and Hypotheses}

We first propose a mediation model of LMX, psychological empowerment and affective well-being. Subsequently, we introduce the concept of the employment relationship, and its role as a moderator in this model.

\section{Psychological Empowerment as a Mediator}

LMX theory postulates that leaders do not offer the same tangible and intangible resources and support such as information, meaningful work and participation opportunities to all of their subordinates (Graen \& Uhl-Bien, 1995). LMX refers to the quality of the exchange relationship among leaders and their individual subordinates (Dansereau Jr, Graen, \& Haga, 1975). Low-quality LMX involves a transactional relationship that is restricted to the employment contract. High-quality LMX involves an exchange based on mutual respect, affect, contributions, and loyalty (Liden \& Maslyn, 1998).

Consistent with previous research, we regard job satisfaction and emotional exhaustion as affective well-being (Decramer et al., 2015; Van Horn, Taris, Schaufeli, \& Schreurs, 2004). Whereas job satisfaction is about the experienced pleasure at work (Schaufeli \& Dierendonck, 2004), emotional exhaustion deals with feelings of being overextended and depleted of emotional resources (Schaufeli \& Dierendonck, 2004). As mentioned in the introduction, the direct link between LMX and affective well-being has been well established (Dulebohn et al., 2012; Gerstner \& Day, 1997). In addition to this direct linkage, mediators are seen as potentially relevant in the LMX-outcomes relationship (Aryee \& Zhen Xiong, 2006). The current article examines psychological empowerment as one way in which LMX quality may relate to affective well-being. 
Thomas and Velthouse (1990) maintained that psychologically empowered employees are more resilient. Given its motivational underpinnings (Aryee \& Zhen Xiong, 2006; Spreitzer, 2007), psychological empowerment may partly explain why LMX and affective well-being are related. Empowerment theory suggests that employees that are psychologically empowered perceive their work goals to be meaningful. Employees experience the necessary competencies, impact and autonomy to do their work (Spreitzer, 1995; Thomas \& Velthouse, 1990). In high-quality LMX, these cognitions about work may be fostered. Leaders enable meaningful work and provide access to growth opportunities and information (Aryee \& Zhen Xiong, 2006; Liden et al., 2000). Additionally, leaders have great professional respect for employees with whom they have a high-quality LMX (Scandura \& Pellegrini, 2008). Metaanalysis indeed supports that subordinates feel empowered as a result of LMX quality (Dulebohn et al., 2012).

In turn, we expect that employees' well-being is fostered. On the one hand, evidence has suggested that employees' intrinsic need to find a satisfying purpose (job satisfaction) is addressed by experiencing their jobs as meaningful (Seibert, Silver, \& Randolph, 2004; Seibert, Wang, \& Courtright, 2011; Spreitzer, 1995, 2007). On the other hand, psychological empowerment provides employees with resources to cope with their work demands and feel in control over their work, which reduces emotional exhaustion (Seibert et al., 2011; Spreitzer, 2007).

Thus, we expect that psychological empowerment acts as a mediator in the relationship between LMX and affective well-being. As mentioned, LMX may also affect affective well-being through other means. Therefore, we expect this mediation to be partial rather than full (Muller, Judd, \& Yzerbyt, 2005). We hypothesize, 
Hypothesis 1: Psychological empowerment partially mediates the relationship between LMX quality and affective well-being.

\section{Employment Relationship}

Employment relationship is introduced as a moderator in the hypothesized mediated relationship between LMX quality and affective well-being. Before building arguments for the joint role of LMX and the employment relationship in this linkage, we first focus on the concept of 'employment relationship'.

Building on the inducement-contribution model (March \& Simon, 1958), the employment relationship is viewed as an exchange of organizational inducements for employee contributions (Tsui et al., 1997). Tsui and Wang (2002) (pp. 105-106) further conceptualize the employment relationship "as the employer's expectations of contributions desired from the employees and inducements the employer actually offers.....The relationship is usually defined at the job level." Thus, the employment relationship differs from the psychological contract by representing exchange between the organization and job incumbents, and not the individual perceptions of exchange (Shore et al., 2004; Tsui et al., 1997). Inherent in its definition, the employment relationship exists of two dimensions: (1) The offered inducements involve HRM practices that indicate the employer's investment in the employee (e.g., participation, career development, training investments, job security), and (2) the expected contributions involve HRM practices that entail expectations (e.g., performance requirements pertaining to the quantity and quality of work, continuous improvement, initiative-taking). By combining high/broad and low/narrow levels of inducements and contributions, Tsui et al. (1997) conceptualized about four types of the 
employment relationship: mutual investment, overinvestment, quasi-spot contracts, and underinvestment.

Mutual investment and overinvestment are conceptually related to high-commitment work systems because they imply investments that allow employees to develop their competencies and careers (Tsui et al., 1997). Employees enjoy materially rewarding conditions such as interesting wages, bonuses, and employment security (Jiwen Song, Tsui, \& Law, 2009; Wang, Tsui, Zhang, \& Ma, 2003). In addition to these material rewards, employees also enjoy developmental rewards. They can assume responsibility, and their suggestions and decisions are respectfully valued (Jia et al., 2014; Zhang et al., 2008). Unlike overinvestment, mutual investment implies high expectations such as taking on additional assignments, assisting junior colleagues, and learning firm-specific skills (Hom et al., 2009; Tsui et al., 1997).

Further, quasi-spot contracts and underinvestment entail few rewarding and developmental resources (Tsui \& Wang, 2002). In quasi-spot contracts, employees are only required to fulfill the well-specified, limited duties of the employment contract. Underinvestment implies high job requirements compared to what is offered. The employer does not offer an open-ended job but expects full engagement (Tsui et al., 1997).

\section{Employment Relationship as a Moderator}

It is our aim to expand our understanding of the joint role of LMX and the employment relationship. Specifically, we propose that the extent to which LMX is associated with affective well-being via psychological empowerment, depends on the employment relationship. The relationship between LMX quality and psychological empowerment may be stronger when the employment relationship is consistent with LMX quality. 
When espoused and inferred messages are consistent, it becomes more likely that employees will display the desired behaviors by the organization (Bowen \& Ostroff, 2004). Consistent espoused and inferred messages from HRM and the leader are theorized to be important for a strong, effective HRM system. There is inconsistency when espoused and inferred messages 'deal with the same content area, but they are incongruent or contradictory' (Bowen \& Ostroff, 2004, p. 211).

On the one hand, the employment relationship may be conceptualized as signaling the values espoused by a job. The employer sets the tone of the exchange by signaling the degree of social exchange (Tsui et al., 1997). Employees interpret mutual investment and overinvestment as signals of social exchange. The organization recognizes employees' contributions by investing in them, taking care of their well-being, and considering their needs (Hom et al., 2009; Jiwen Song et al., 2009). Employees form perceptions of the organization's long-term investments, unspecified give-and-take and trust (Shore, Tetrick, Lynch, \& Barksdale, 2006). In contrast, quasi-spot contracts and underinvestment signal that the organization prefers short-term, formal contractual relations. The employer's orientation on social exchange is low (Jiwen Song et al., 2009; Tsui et al., 1997). Accordingly, quasi-spot contracts and underinvestment have been found to lower employees' perceptions of social exchange (Hom et al., 2009; Jiwen Song et al., 2009). By working in a job with few resources, these job incumbents experience that the organization does not value them enough to provide access to resources such as first-hand information and tasks with responsibilities (Zhang, Song, Tsui, \& Fu, 2014). The employment relationship may thus be perceived by the employee as the espoused extent of social exchange.

On the other hand, the degree of LMX may be regarded as the individually inferred social exchange. It is theoretically and empirically established that leaders form different degrees of social exchange with each of their subordinates (Dulebohn et al., 2012; Graen \& 
Uhl-Bien, 1995). As LMX quality increases, leaders take greater care of employees.

Employees feel valued and respected for their professional contribution (Liden \& Maslyn, 1998). Because the leader is seen as an agent of the organization (Eisenberger, Stinglhamber, Vandenberghe, Sucharski, \& Rhoades, 2002), employees are likely to experience a long-term social exchange relationship with the organization (Loi et al., 2009).

The inferred social exchange from LMX may be consistent or conflicting with the social exchange espoused by the employment relationship. As LMX quality becomes higher, the inferred social exchange signals from mutual investment and overinvestment become more consistent with the espoused signals employees perceive from their leaders. Since consistency is an important part of a strong HRM system (Bowen \& Ostroff, 2004), we expect that consistency among the inferred and espoused social exchange translates into improved psychological empowerment. This consistency creates more clarity about the investments by HRM and the leader. In accordance with the norm of felt obligations in social exchange (Gouldner, 1960), employees engage in desired behaviors in return to the organization by being empowered to contribute to extra-role goals.

On the other hand, when there is inconsistency, employees may be confused (Bowen \& Ostroff, 2004) about whether they will obtain the support to develop their competencies in the future. In the mutual investment and overinvestment employment relationship, low-quality LMX may result in employees perceiving to get the least meaningful assignments, to lack impact even though their jobs offer participation, and to doubt that their investments in the organization pay off in the long run. Similarly, in the underinvestment and quasi-spot employment relationship, high-quality LMX may cause a lack of clarity about organizational expectations and rewards, which is likely to attenuate functional employee attitudes (Bowen \& Ostroff, 2004) such as psychological empowerment. 
Thus, as LMX quality becomes higher it signals values about social exchange that are consistent with mutual investment and overinvestment. Consequently, LMX quality may be more strongly related to psychological empowerment for employees in these employment relationships (relative to underinvestment and quasi-spot contract). In turn, as mentioned, we expect that the cognitions of empowerment relate to affective well-being (higher job satisfaction and lower emotional exhaustion). This reasoning implies a moderated mediation: we expect that the indirect relationship between LMX quality and affective well-being depends on the job's employment relationship. We hypothesize,

Hypothesis 2: The employment relationship moderates the mediation of psychological empowerment in the relationship between LMX quality and affective well-being such that the mediated relationship will be stronger when employees make part of the mutual investment and overinvestment employment relationship (relative to the quasispot contract and underinvestment employment relationship).

\section{Method}

\section{Sample}

Data were collected in 89 jobs in a large public sector organization in Belgium and made part of a larger research project about HRM, well-being, and performance. The studied organization uses job analysis as the basis for the HRM cycle which is important for collective views on the employment relationship to develop at the job level (Klein \& Kozlowski, 2000). For power issues at the second level (Bliese, 2000; Maas \& Hox, 2005), we first selected the job strata and, subsequently, we used a random strategy for the sample. Jobs represented in the sample capture diverse set of jobs, which range from different levels in administrative functions to community-facing roles such as ICT process analysts, software 
engineers, instructors, job coaches, account managers, secretaries, selection officers, payroll specialists, marketing officers, comp\&ben specialists, and accountants. For 'temporal separation' reasons to prevent common method bias (Podsakoff, MacKenzie, Lee, \& Podsakoff, 2003), the dependent variables (i.e., job satisfaction and emotional exhaustion) were collected with a time lag of three months. A total of 1209 respondents (67\%) filled out the first survey, and after three months, 934 of these respondents (78\%) reported job satisfaction and emotional exhaustion. This process led to data on 82 jobs. A total $13,5 \%$ of the respondents held management functions. Respondents were 44 years old on average (SD 11), had been employed by the organization for an average period of 17 years (SD 5.13), and held their current job for approximately eight years (SD 6.9). Males represented 33\% of the sample. A vast majority of employees had a bachelor (46\%) or master degree (32\%).

\section{Measures}

We adopted Dutch translations of measures (psychological empowerment from Dewettinck and van Ameijde (2011); emotional exhaustion from Schaufeli and Van Dierendonck (2004)), and we applied blind back-translation (Cascio, 2011).

\section{Employment relationship}

We measured employment relationship using 17 items for offered inducements (i.e., material and developmental resources) and 13 items for expected contributions (i.e., in-role and extrarole expectations). We used the scale from Jia et al. (2014) for developmental resources, inrole requirements, and extra-role requirements, and the scale from Jiwen Song et al. (2009) for material rewards. One item was dropped because it was not appropriate for the Belgian context (i.e., provide generous housing subsidies beyond legal requirements). Example items for the offered inducements are: ' $<J o b$ referent $>$ who desire promotions have more than one 
potential position to which they could be promoted,' and ' $<$ Job referent $>$ can expect to stay in the organization for as long as they wish'; example items for expected contributions are ' $<$ Job referent $>$ are required to...contribute to the future development of the company or department' and '...continuously improve work procedures and methods.' We used the correct referents (job titles) in the items which is important in multilevel research (Klein \& Kozlowski, 2000), and it creates a psychological separation that prevents common method bias (Podsakoff et al., 2003).

We study job incumbents' collective perceptions of the employment relationship that operate more centrally in the HRM-performance chain than organizational intentions (Bowen \& Ostroff, 2004). Aggregation to the job level was justified by theory (Tsui et al., 1997) and supported by significant between-job differences from the ANOVA test and high rwg values (i.e., in-role expectations: $\mathrm{F}(81,850)=1.43$, $\mathrm{p}<0.05$, rwg values $=0.90$; extra-role expectations: $\mathrm{F}(81,848)=2.52, \mathrm{p}<0.001$, rwg values $=0.81$; developmental rewards: $\mathrm{F}(81,851)=1.89$, $\mathrm{p}<0.001$, rwg values $=0.82 ;$ material rewards: $\mathrm{F}(81,850)=2.18, \mathrm{p}<0.001$, rwg values $=0.88)$ (Bliese, 2000).

Finally, these aggregated dimensions were used in a k-means cluster analysis of the employment relationship that was established by Wang, Tsui, Zhang, and Ma (2003). The empirically derived clusters correspond to mutual investment (28 jobs; developmental

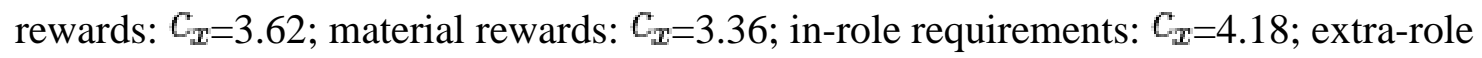

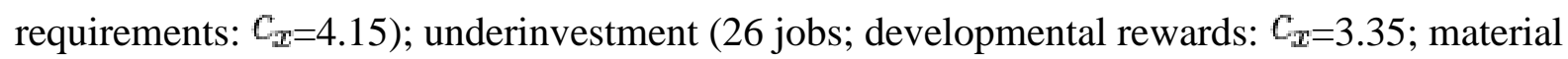

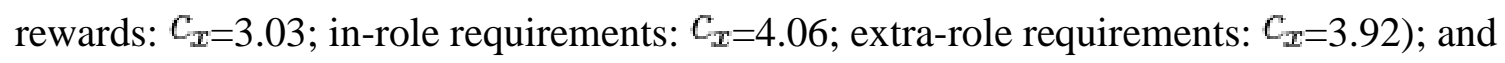
quasi-spot contracts (28 jobs; developmental rewards: $c_{x=3.12}$; material rewards: $c_{x}=3.16$;

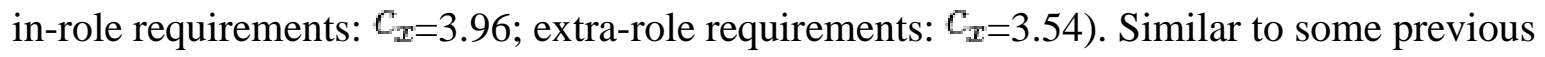


research (Bornay-Barrachina, De la Rosa-Navarro, López-Cabrales, \& Valle-Cabrera, 2012; Jiwen Song et al., 2009), our cluster analysis did not locate over-investment in our data.

\section{$L M X$}

We used the LMX scale by Bauer and colleagues (1996). Example items included the following: 'I usually know where I stand with my supervisor' and 'My direct supervisor understands my job problems and needs.' Alpha was 0.93 .

\section{Psychological empowerment}

We used the construct by Spreitzer (1995) for psychological empowerment. Example items included the following: 'The work that I do is important to me' and 'I have mastered the skills necessary for my job.' The commonly reported second-order, four-factor model fits our data $(\mathrm{GFI}=0.93, \mathrm{CFI}=0.93, \mathrm{NFI}=0.92)$. Alpha was 0.87 .

\section{Job satisfaction}

We used the measure of job satisfaction by Cammann et al. (1983). Example items included the following: 'All in all, I am satisfied with my job' and 'In general, I like working here.' Alpha was 0.84 .

\section{Emotional exhaustion}

We used six items from the Maslach Burnout Inventory to measure emotional exhaustion (Schaufeli \& Dierendonck, 2004). Example items included the following: 'I feel fatigued when I get up in the morning and have to face another day on the job' and 'I feel emotionally drained from my work.' Alpha was 0.87.

\section{Control variables}


First, because job tenure causes differences in knowledge, skill, and/or experience (Seibert et al., 2011), we used job tenure as a control variable. In addition, we decided to include gender based on Kanter's (1977) suggestion that women are given little power in organizations and that they thus feel less psychologically empowered. Second, we also took between-job differences in psychological empowerment into account. Different types of jobs are likely to vary in terms of human capital and impact at work (Seibert et al., 2011). Research shows that managers are more empowered (Ergeneli, Arı, \& Metin, 2007). It is also important to control for managers because they are involved with exchange relationships with their own leaders and subordinates. We controlled for job type, with managers coded as ' 1 ' and non-managers coded as '0.'

\section{Analyses}

We used hierarchical linear modeling (HLM), with full maximum likelihood, which is suitable to test cross-level relations with individual data nested in higher levels (Hox, 2010). Pseudo $\mathrm{R}^{2}$ is calculated (Snijders \& Bosker, 1994), and deviance is reported as an indicator of fit ('the smaller, the better the model') (Hox, 2010).

As recommended by Aguinis, Gottfredson, and Culpepper (2013), our estimations avoided spurious cross-level interactions by using group-mean centering. We followed Muller, Judd, and Yzerbyt (2005) for testing moderated mediation: (i) LMX is significantly related with affective well-being. This effect does not depend on the moderator; (ii) There is a mediation via psychological empowerment; (iii) The effect from LMX on psychological empowerment (i.e., mediator) depends on the employment relationship; and (iv) The indirect effect of LMX on affective well-being via psychological empowerment is stronger for employees in the mutual investment employment relationship relative to underinvestment and quasi-spot 
contract. In order to test the significance of the indirect mediation effects, we have estimated the indirect effects using the Monte Carlo method by Selig and Preacher (2008).

\section{Results}

Table 1 presents the means, standard deviations, and correlations. We caution that the correlations with offered inducements and expected contributions may be biased because they do not take into account the nested structure of the data. Below, we first report the tests for mediation and subsequently for moderation. We estimated the models that were proposed by Muller et al. (2005).

\section{Insert Tables 1, 2, 3 and 4 about here}

\section{Tests of LMX and affective well-being}

We tested the first condition of moderated mediation by analyzing the relationship between LMX and the two outcomes (Table 2: job satisfaction; and Table 3: emotional exhaustion).

The intercept-only model showed significant between-job variance for both job satisfaction and emotional exhaustion. HLM is thus appropriate (Hox, 2010). We then estimated models 2A and 2B with level 1 and level 2 controls. This showed that gender is significantly associated with emotional exhaustion $(\beta=0.08, \mathrm{p}<0.10)$. Models $3 \mathrm{~A}$ and $3 \mathrm{~B}$ show that LMX increased job satisfaction $(\beta=0.25, p<0.001)$ and lowered emotional exhaustion $(\beta=-0.21, p$ $<0.001$ ), which supports the first condition of moderated mediation.

Furthermore, models 4A and 4B tested for non-hypothesized cross-level interactions between the employment relationship and LMX, which led to no significant results. Job satisfaction 
was significantly lower under quasi-spot contracts $(\beta=-0.18, \mathrm{p}<0.01)$ and underinvestment $(\beta=-0.10, p<0.10)$ than under mutual investment.

\section{Mediation tests}

We then tested the second condition: whether psychological empowerment functions as a mediator. First, we tested whether LMX affects psychological empowerment in Table 4. We began with an intercept-only model. The between-job errors showed significant variance $(\mathrm{p}<0.05)$. We then estimated model 2 , including the control variables only. The results suggest that managers had higher levels of psychological empowerment $(\beta=0.23, p<0.001)$, and that women were less empowered $(\beta=-0.06, \mathrm{p}<0.10)$. We then proceeded with model 3 , which included the predictors. LMX was positively associated with psychological empowerment $(\beta=0.22, \mathrm{p}<0.001)$. Furthermore, quasi-spot contracts were negatively associated with psychological empowerment relative to mutual investment $(\beta=-0.17, p<0.01)$.

Turning back to Tables 2 and 3, we added psychological empowerment to the equation in models 5A $(\beta=0.50, p<0.001)$ and 5B $(\beta=-0.39, p<0.001)$. Because the coefficient for LMX decreased for job satisfaction $(\beta=0.08, \mathrm{p}<0.10)$, psychological empowerment was found to partially mediate the relationship between LMX and job satisfaction which provides support for hypothesis 1 . For emotional exhaustion the coefficient turned insignificant which suggest a full mediation of LMX and emotional exhaustion through psychological empowerment rather than a partial mediation. Following Selig and Preacher (2008), we estimated the significance of the indirect effects. Results show significant indirect effects for the outcome of job satisfaction (95 per cent CIs between 0.08 and 0.14), and for emotional exhaustion (95 per cent CIs between -0.12 and -0.06). Taken together, the findings provide support for the second condition of moderated mediation. 
We estimated models 6A and 6B to test for not hypothesized cross-level interactions.

Deviance did not change, which suggests that models 5A and 5B are preferable.

\section{Moderation tests}

We now turn to the test of the third condition in Table 4 (Model 4). Consistent with the third condition, we found that the employment relationship moderates the relationship between LMX and psychological empowerment. The estimates for Deviance suggest a better fit for this model compared with the model without the cross-level moderator. Since Mutual investment, underinvestment and quasi-spot contract are values of the categorical moderator of the employment relationship, the coefficients provide the simple slopes of the categories relative to the referent category. Model 4a shows a stronger relationship between LMX and psychological empowerment in mutual investment jobs (LMX X underinvestment: $\beta=-0.16$, $\mathrm{p}<0.001 ;$ LMX X quasi-spot contract: $\beta=-0.07, \mathrm{p}>0.10$ ). Model $4 \mathrm{~b}$ further supports that relationship between LMX and psychological empowerment is stronger in mutual investment jobs (LMX X mutual investment: $\beta=0.10, \mathrm{p}<0.05$ ).

\section{Insert Figure 2 about here}

In order to further interpret the nature of the moderation, we follow recommendations to plot the interaction (Dawson, 2014). Figure 2 provides a graphical presentation of the cross-level interaction. The slope for mutual investment is the steepest, which provides support for the expectation that the linkage between LMX and psychological empowerment is strongest for employees in the mutual investment employment relationship. 


\section{Moderated mediation tests}

To assess the final condition of moderated mediation, we examined whether the indirect effect of LMX on affective well-being via psychological empowerment differs depending on the employment relationship. We bootstrapped 95 per cent CIs (Selig \& Preacher, 2008). For job satisfaction, the results revealed that the extent to which psychological empowerment mediates differs depending on the employment relationship (mutual investment: 95 per cent CIs between 0.01 and 0.10 ; underinvestment: 95 per cent CIs between -0.13 and -0.03 ; quasispot contract: 95 per cent CIs between -0.08 and 0.01 ). The tests for emotional exhaustion revealed a similar pattern (mutual investment: 95 per cent CIs between -0.08 and -0.01 ; underinvestment: 95 per cent CIs between 0.02 and 0.10; quasi-spot contract: 95 per cent CIs between -0.01 and 0.07 ). For both job satisfaction and emotional exhaustion, CIs show that the mediation is stronger for employees in the mutual investment employment relationship relative to other the employment relationships which supports hypothesis 2 .

Taken together, we found support for the four conditions of moderated mediation. The indirect effect of LMX on affective well-being via psychological empowerment is found to be stronger for employees in the mutual investment employment relationship.

\section{Discussion}

\section{Theoretical implications}

This study addresses the joint role of the leader and HRM. We build on theorizing about the HRM system strength (Bowen \& Ostroff, 2004) to examine when LMX is related to 
affective well-being via psychological empowerment. We examined the employment relationship as a moderator. As hypothesized, we found a mediating role of psychological empowerment in the relationship between LMX and affective well-being (i.e., job satisfaction and emotional exhaustion). We also found support for moderated mediation. Psychological empowerment provides more explanation as a mediator for LMX and affective well-being when employees work in a mutual investment employment relationship.

Considering the relevancy to study the joint role of the leader and HRM (Kuvaas \& Dysvik, 2010; Purcell \& Hutchinson, 2007), the key contribution of this study lays in the role of the employment relationship in our mediated moderation model. We found that when the job-level employment relationship and LMX consistently signal social exchange, there is a stronger effect on psychological empowerment and, indirectly, on affective wellbeing. In line with theorizing in HRM literature (Bowen \& Ostroff, 2004; Liu et al., 2003), this suggests that the consistency of signals from HRM and the leader is important to employee reactions. Accordingly, Kuvaas and Dysvik (2010) found that both the perceived investments in employee development and perceived supervisory support need to be high in order to be effective for employee attitudes and performance. We add to this work that consistency is also relevant to understand the joint role of the job-level employment relationship and LMX. Employees are most empowered when high-quality LMX is coupled with a mutual investment employment relationship. In these circumstances, the espoused and inferred messages from HRM and the leader consistently signal social exchange. This consistency creates clarity about the investments on which employees respond by being empowered. In turn, these feelings of empowerment enhance affective well-being. The first key contribution of this study thus is about the importance of consistency of the employment relationship and LMX pertaining to social exchange signals. Supportive leader behaviors such 
as in high-quality LMX are most effective when they take place in the context of HRM systems that also signal social exchange.

Not only does this study add to our understanding of the extent to which leader behaviors and HRM systems should be consistent, this study also adds to the understanding of whether leader behaviors and HRM systems can compensate for each other. Our findings add to the existing research by suggesting that a compensation perspective is also relevant to our understanding of the joint role of HRM and the leader. We found that high-quality LMX compensates for employment relationships with low offered resources. Although the slopes of LMX are attenuated for employees in the underinvestment and quasi-spot employment relationship, these slopes are still positive (see Figure 2). This finding suggests that the leader can to some extent compensate for HRM that signals an economic exchange orientation. More specifically, resources from LMX quality can compensate for low resources of the employment relationship. This finding provides support for the suggestion in the employeeorganization relationship literature that employees value resources that are unavailable from other exchanges (Buch, 2014; Cropanzano \& Mitchell, 2005; Shore, Coyle-Shapiro \& Chang, in press). Our second key contribution thus is that leader behaviors in the form of LMX can to some extent substitute for HRM systems such as the jobs' employment relationships. This is compelling: both the consistency perspective and the compensation perspective add to our understanding of the joint role of HRM and the leader.

Moreover, we add to the existing research by finding that the compensation of resources from the leader for resources from HRM systems does not work in both directions. Although LMX can compensate for the employment relationship, we found no support for the reverse. The mutual investment employment relationship does not compensate for low-quality LMX (see Figure 2). This may be due to a stronger effect of the leader in the joint role of HRM and the leader. Accordingly, HRM is conceptualized as more distal to employee reactions than 
interventions from the leader (Nishii \& Wright, 2008). Therefore, the leader may take a dominant role in compensating for low resources from HRM. This may also explain why previous HRM research does not support the compensatory role of resources from HRM and the leader (Kuvaas \& Dysvik, 2010). By conceptualizing HRM as a continuum from low to high commitment rather than as distinct HRM approaches, past research may have been unable to show how the leader compensates for transactional HRM approaches. Thus, our findings add to the existing research by studying multiple distinct HRM approaches instead of a continuum from low to high commitment (Guest et al., 2012; Hauff et al., 2014). This approach has allowed us to further unravel the joint role of HRM and the leader. We found support for the relevancy of consistency of HRM systems and leader behaviors, as well as for the relevancy of compensation of resources from the leader for lacking resources from HRM systems, but not vice versa.

\section{Limitations}

Because of the moderation of the link between LMX and psychological empowerment by the employment relationship, common method bias is unlikely to be a problem in this research (Siemsen, Roth, \& Oliveira, 2010). Nevertheless, the contributions of this study should be viewed in light of certain limitations. First, the direction of causality is unclear. Exchange relationships develop incrementally and entail a continuous process of give and take. Thus, employee outcomes also generate leader behaviors that can in turn influence LMX quality (Cropanzano \& Mitchell). Furthermore, we considered the nesting structure of employees within the job, but employees are also nested within other levels. In this regard, LMX differentiation, which is studied in past research, acknowledges the nested structure of the leader (Henderson et al., 2009). Finally, we believe that it may also be relevant to look at LMX differentiation within the nested structure of the job. When multiple leaders manage 
employees with the same job, it may be that employees perceive that leaders offer more to employees that are nested within other leaders. Future research may address the consequences of such job-level LMX differentiation.

\section{Implications for practitioners}

HRM and the leader play a joint role in affecting employee reactions. Because LMX relationships are important for psychological empowerment and affective well-being, organizations should foster high-quality LMX. However, this linkage depends on the employment relationship. The empowering potential of high-quality LMX may be reduced when the employment relationship entails few offered inducements.

HR managers should realize that LMX particularly empowers affective well-being when employees work in a mutual investment employment relationship. The best results for psychological empowerment are reached when high-quality LMX is coupled with mutual investment. When mutual investment goes together with a low-quality LMX, the empowering effect is much lower. For HR managers, this stresses the pivotal role of the LMX quality in gaining the optimal benefits from the mutual investment employment relationship.

Leaders who manage employees with different jobs should be aware that the effectiveness of their efforts to empower employees may depend on employees' job. For employees in an underinvestment and quasi-spot employment relationship, high-quality LMX may be less empowering despite their leaders' efforts.

In sum, our findings point at the relevancy to foster high-quality LMX coupled with a mutual investment employment relationship. On the one hand, LMX quality can be fostered by coaching and rewarding leaders on developing LMX quality relationships with their 
subordinates. On the other hand, the mutual investment employment relationship can be fostered by offering high-commitment HRM practices to the employees.

\section{Conclusion}

The employment relationship and LMX play a joint role in empowering employees, and this indirectly affects their job satisfaction and resilience to deal with job demands. The best results for psychological empowerment are obtained when the employment relationship and LMX consistently signal social exchange, which is when mutual investment is coupled with high-quality LMX. Furthermore, high-quality LMX compensates to some extent for the underinvestment and quasi-spot employment relationship, but mutual investment does not compensate for low-quality LMX. Future research may continue to unravel the joint role of HRM systems and leader behaviors from a consistency and compensation perspective. 


\section{References}

Aguinis, H., Gottfredson, R. K., \& Culpepper, S. A. (2013). Best-Practice Recommendations for Estimating Cross-Level Interaction Effects Using Multilevel Modeling. Journal of Management, 39(6), 1490-1528.

Aryee, S., \& Zhen Xiong, C. (2006). Leader-member exchange in a Chinese context: Antecedents, the mediating role of psychological empowerment and outcomes. Journal of Business Research, 59(7), 793-801.

Bauer, T. N., Green, S. G., \& Bauer, T. N. (1996). Development of Leader-Member Exchange: A Longitudinal Test. The Academy of Management Journal, 39(6), 1538-1567.

Bliese, P. D. (2000). Within-group agreement, non-independence, and reliability: Implications for data aggregation and analysis. In K. J. Klein \& S. W. J. Kozlowski (Eds.), Multilevel theory, research, and methods in organizations: foundations, extensions, and new directions (Vol. xxix, pp. 467-511). San Francisco, CA, US: Jossey-Bass.

Bornay-Barrachina, M., De la Rosa-Navarro, D., López-Cabrales, A., \& Valle-Cabrera, R. (2012). Employment Relationships and Firm Innovation: The Double Role of Human Capital. British Journal of Management, 23(2), 223-240.

Bowen, D. E., \& Ostroff, C. (2004). Understanding HRM-firm performance linkages: the role of the "strength" of the HRM system Academy of Management Review, 29(2), 203-221.

Buch, R. (2014). Leader-member exchange as a moderator of the relationship between employeeorganization exchange and affective commitment. The International Journal of Human Resource Management, 26(1), 59-79.

Cammann, C., Fichman, M., Jenkins, D., \& Klesh, J. R. (1983). Assessing organizational change: A guide to methods, measures, and practices. New York: Wiley.

Cascio, W. F. (2011). Methodological issues in international HR management research. The International Journal of Human Resource Management, 23(12), 2532-2545.

Cropanzano, R., \& Mitchell, M. S. (2005). Social Exchange Theory: An Interdisciplinary Review. Journal of Management, 31(6), 874-900.

Dansereau Jr, F., Graen, G. B., \& Haga, W. J. (1975). A vertical dyad linkage approach to leadership within formal organizations: A longitudinal investigation of the role making process. Organizational Behavior and Human Performance, 13(1), 46-78.

Dawson, J. F. (2014). Moderation in Management Research: What, Why, When, and How. Journal of Business and Psychology, 29(1), 1-19.

Decramer, A., Audenaert, M., Van Waeyenberg, T., Claeys, T., Claes, C., Vandevelde, S., . . Crucke, S. (2015). Does performance management affect nurses' well-being? Evaluation and Program Planning, 49(0), 98-105.

Dewettinck, K., \& van Ameijde, M. (2011). Linking leadership empowerment behaviour to employee attitudes and behavioural intentions: Testing the mediating role of psychological empowerment. Personnel Review, 40(3), 284-305.

Dulebohn, J. H., Bommer, W. H., Liden, R. C., Brouer, R. L., \& Ferris, G. R. (2012). A Meta-Analysis of Antecedents and Consequences of Leader-Member Exchange: Integrating the Past With an Eye Toward the Future. Journal of Management, 38(6), 1715-1759.

Eisenberger, R., Stinglhamber, F., Vandenberghe, C., Sucharski, I. L., \& Rhoades, L. (2002). Perceived Supervisor Support: Contributions to Perceived Organizational Support and Employee Retention. Journal of Applied Psychology, 87(3), 565-573.

Ergeneli, A., Ar1, G. S. 1., \& Metin, S. (2007). Psychological empowerment and its relationship to trust in immediate managers. Journal of Business Research, 60(1), 41-49.

Gerstner, C. R., \& Day, D. V. (1997). Meta-Analytic review of leader-member exchange theory: Correlates and construct issues. Journal of Applied Psychology, 82(6), 827-844.

Gilbert, C., De Winne, S., \& Sels, L. (2011). The influence of line managers and HR department on employees' affective commitment. International Journal of Human Resource Management, 22(8), 1618-1637.

Gouldner, A. W. (1960). The Norm of Reciprocity: A Preliminary Statement. American Sociological Review, 25(2), 161-178. 
Graen, G. B., \& Uhl-Bien, M. (1995). Development of leader-member exchange (LMX) theory of leadership over 25 years: Applying a multi-level multi-domain perspective. The Leadership Quarterly, 6(2), 216-247.

Guest, D., Paauwe, J., \& Wright, P. (2012). HRM and performance: achievements and challenges (J. W. Sons Ed.).

Hauff, S., Alewell, D., \& Hansen, N. K. (2014). HRM systems between control and commitment: occurrence, characteristics and effects on HRM outcomes and firm performance. Human Resource Management Journal, 24(4), 424-441.

Henderson, D. J., Liden, R. C., Glibkowski, B. C., \& Chaudhry, A. (2009). LMX differentiation: A multilevel review and examination of its antecedents and outcomes. The Leadership Quarterly, 20(4), 517-534.

Hom, P. W., Tsui, A. S., Wu, J. B., Lee, T. W., Zhang, A. Y., Fu, P. P., \& Li, L. (2009). Explaining Employment Relationships With Social Exchange and Job Embeddedness. Journal of Applied Psychology, 94(2), 277-297.

Hox, J. J. (2010). Multilevel analysis. Techniques and applications. 2nd Edition. New York: Routledge.

Jia, L., Shaw, J., Tsui, A., \& Park, T.-Y. (2013). A social-structural perspective on employeeorganization relationships and team creativity. Academy of Management Journal, 57(3), 869891.

Jiwen Song, L., Tsui, A. S., \& Law, K. S. (2009). Unpacking employee responses to organizational exchange mechanisms: the role of social and economic exchange perceptions. Journal of Management, 35(1), 56-93.

Klein, K. J., \& Kozlowski, S. W. J. (2000). From Micro to Meso: Critical Steps in Conceptualizing and Conducting Multilevel Research Organizational Research Methods, 3(3), 211-236.

Kuvaas, B., \& Dysvik, A. (2010). Exploring alternative relationships between perceived investment in employee development, perceived supervisor support and employee outcomes. Human Resource Management Journal, 20(2), 138-156.

Liden, R. C., \& Maslyn, J. M. (1998). Multidimensionality of Leader-Member Exchange: An Empirical Assessment through Scale Development. Journal of Management, 24(1), 43-72.

Liden, R. C., Wayne, S., \& Sparrowe, R. (2000). An Examination of the Mediating Role of Psychological Empowerment on the Relations Between the Job, Interpersonal Relationships, and Work Outcomes. Journal of Applied Psychology, 85(3), 407-416.

Liu, W., Lepak, D. P., Takeuchi, R., \& Sims, H. P. (2003). Matching leadership styles with employment modes: strategic human resource management perspective. Human Resource Management Review, 13(1), 127-152.

Loi, R., Mao, Y., \& Ngo, H.-y. (2009). Linking Leader-Member Exchange and Employee Work Outcomes: The Mediating Role of Organizational Social and Economic Exchange. Management and Organization Review, 5(3), 401-422.

Maas, C. J. M., \& Hox, J. J. (2005). Sufficient sample sizes for multilevel modeling. Methodology: European Journal of Research Methods for the Behavioral and Social Sciences, 1(3), 86-92.

Muller, D., Judd, C. M., \& Yzerbyt, V. Y. (2005). When Moderation Is Mediated and Mediation Is Moderated. Journal of Personality \& Social Psychology, 89(6), 852-863.

Nishii, L. H., \& Wright, P. M. (2008). Variability at multiple levels of analysis: Implications for strategic human resource management. In D. Smith (Ed.), The people make the place (pp. 225-248). Mahwah, NJ: Erlbaum.

Pan, J.-z., Zhou, X.-X., \& Zhou, X.-q. (2010). The role of leadership between the employee and the organization: a bridge or a ravine? An empirical study from China. Journal of management and marketing research, 5, 1-14.

Podsakoff, P. M., MacKenzie, S. B., Lee, J.-Y., \& Podsakoff, N. P. (2003). Common method biases in behavioral research: A critical review of the literature and recommended remedies. Journal of Applied Psychology, 88(5), 879-903.

Purcell, J., \& Hutchinson, S. (2007). Front-line managers as agents in the HRM-performance causal chain: theory, analysis and evidence. Human Resource Management Journal, 17(1), 3-20.

Scandura, T. A., \& Pellegrini, E. K. (2008). Trust and Leader-Member Exchange A Closer Look at Relational Vulnerability. Journal of Leadership \& Organizational Studies, 15(2), 101-110. 
Schaufeli, W. B., \& Dierendonck, D. v. (2004). Handleiding van de Utrechtse Burnout Schaal (UBOS): Swets \& Zeitlinger.

Seibert, S. E., Silver, S. R., \& Randolph, W. A. (2004). Taking Empowerment to the Next Level: A Multiple-Level Model of Empowerment, Performance, and Satisfaction. The Academy of Management Journal, 47(3), 332-349.

Seibert, S. E., Wang, G., \& Courtright, S. (2011). Antecedents and consequences of psychological and team empowerment in organizations: a meta-analytic review. Journal of Applied Psychology, 96(5), 981-1003.

Selig, J. P., \& Preacher, K. J. (2008). Monte Carlo method for assessing mediation: An interactive tool for creating confidence intervals for indirect effects [Computer software].

Shaw, J. D., Dineen, B. R., Fang, R., \& Vellella, R. F. (2009). Employee-organization relationships, HRM practices, and quit rates of good and poor performers. The Academy of Management Journal, 52(5), 1016-1033.

Shore, L. M., Coyle-Shapiro, J. A-M., Chang, C. Exchange in the Employee-Organization Relationship. (in press). In N. Anderson, D. S. Ones, H. K. Sinangil \& C. Viswesvaran (Eds.), Handbook of Industrial, Work, and Organizational Psychology - 2nd Edition. London: Sage.

Shore, L. M., Tetrick, L. E., Lynch, P., \& Barksdale, K. (2006). Social and Economic Exchange: Construct Development and Validation. Journal of Applied Social Psychology, 36(4), 837-867.

Shore, L. M., Tetrick, L. E., Taylor, M. S., Coyle-Shapiro, J., Liden, R., McLean Parks, J., Morrison, E. W., Porter, L. W., Robinson, S., Roehling, M., Rousseau, D., Schalk, R., Tsui, A., \& Van Dyne, L. (2004). The employee-organization relationship: A timely concept in a period of transition. In J. Martocchio (Ed.), Research in personnel and human resources management (Vol. 23, pp. 291-370). Greenwich, CT: JAI Press.

Siemsen, E., Roth, A., \& Oliveira, P. (2010). Common Method Bias in Regression Models With Linear, Quadratic, and Interaction Effects. Organizational Research Methods, 13(3), 456-476.

Skakon, J., Nielsen, K., Borg, V., \& Guzman, J. (2010). Are leaders' well-being, behaviours and style associated with the affective well-being of their employees? A systematic review of three decades of research. Work \& Stress, 24(2), 107-139.

Snijders, T., \& Bosker, R. (1994). Modeled Variance in Two-Level Models. Sociological Methods Research, 22(3), 342-363.

Spreitzer, G. M. (1995). Psychological Empowerment in the Workplace: Dimensions, Measurement, and Validation. The Academy of Management Journal, 38(5), 1442-1465.

Spreitzer, G. M. (2007). Taking Stock: A review of more than twenty years of research on empowerment at work. In C. Cooper \& J. Barling (Eds.), The Handbook of Organizational Behavior: Sage Publications.

Thomas, K. W., \& Velthouse, B. A. (1990). Cognitive Elements of Empowerment: An "Interpretive" Model of Intrinsic Task Motivation. The Academy of Management Review, 15(4), 666-681.

Tsui, A. S., Pearce, J. L., Porter, L. W., \& Tripoli, A. M. (1997). Alternative approaches to the employeeorganization relationship: does investment in employees pay off. Academy of Management Journal, 40(5), 1089-1997.

Tsui, A. S., \& Wang, D. (2002). Employment relationships from the employer's perspective: current research and future directions. International review of industrial and organizational psychology, 17, 77-112.

Tsui, A. S., \& Wu, J. B. (2005). The new employment relationship versus the mutual investment approach: Implications for human resource management. Human Resource Management, 44(2), 115-121.

Van Horn, J. E., Taris, T. W., Schaufeli, W. B., \& Schreurs, P. J. G. (2004). The structure of occupational well-being: A study among Dutch teachers. Journal of Occupational and Organizational Psychology, 77(3), 365-375.

Wang, D., Tsui, A. S., Zhang, Y., \& Ma, L. (2003). Employment relationships and firm performance: evidence from an emerging economy. Journal of Organizational Behavior, 24(5), 511-535.

Zhang, A. Y., Song, L. J., Tsui, A. S., \& Fu, P. P. (2014). Employee responses to employmentrelationship practices: The role of psychological empowerment and traditionality. Journal of Organizational Behavior, 35(6), 809-830. 
Zhang, A. Y., Tsui, A. S., Song, L. J., Li, C., \& Jia, L. (2008). How do I trust thee? The employeeorganization relationship, supervisory support, and middle manager trust in the organization. Human Resource Management, 47(1), 111-132. 
Table 1: Descriptive Statistics and Correlations at the Individual Level ( $\mathbf{n}=934)$

\begin{tabular}{|c|c|c|c|c|c|c|c|c|c|}
\hline & Means & S.D. & 1 & 2 & 3 & 4 & 5 & 6 & 7 \\
\hline $\begin{array}{l}\text { 1. Psychological } \\
\text { empowerment }\end{array}$ & 3.89 & 0.49 & 1 & & & & & & \\
\hline 2. LMX quality & 3.62 & 0.78 & $0.34 * *$ & 1 & & & & & \\
\hline 3. Job tenure & 8.17 & 6.80 & -0.01 & -0.06 & 1 & & & & \\
\hline 4. Job satisfaction & 4.14 & 0.65 & $0.40 * *$ & $0.31 * *$ & 0.03 & 1 & & & \\
\hline 5. Emotional exhaustion & 2.19 & 0.74 & $-0.28 * *$ & $-0.24 * *$ & -0.01 & $-0.49 * *$ & 1 & & \\
\hline 6. Offered inducements & 3.27 & 0.52 & $0.28 * *$ & $0.43^{* *}$ & -0.04 & $0.43^{* *}$ & $-0.33^{* *}$ & 1 & \\
\hline 7. Expected contributions & 3.94 & 0.49 & $0.34 * *$ & $0.23 * *$ & -0.01 & $0.25 * *$ & -0.00 & $0.31 * *$ & 1 \\
\hline
\end{tabular}

Notes.

$* * \mathrm{p}<0.01 ; * \mathrm{p}<0.05$ 
Table 2: Staged approach to first and second condition of moderated mediation analysis with job satisfaction as outcome

$\begin{aligned} & \text { Intercept- } \\ & \text { only } \\ & \text { model }\end{aligned}$
Model 2A Model 3A $\quad$ Model 4A Model 5A $\quad$ Model 6A

\begin{tabular}{|c|c|c|c|c|c|c|c|}
\hline \multicolumn{8}{|l|}{ Individual level } \\
\hline Intercept & $4.14 * * *$ & $4.09 * * *$ & $4.21 * * *$ & $4.21 * * *$ & $4.19 * * *$ & 4.19 & $* * *$ \\
\hline Gender & & 0.05 & 0.05 & 0.05 & $0.06 \dagger$ & 0.06 & $\dagger$ \\
\hline Job tenure & & 0.00 & $0.01 \dagger$ & $0.01 \dagger$ & 0.00 & 0.00 & \\
\hline LMX & & & $0.25 * * *$ & $0.23 * * *$ & $0.08 \dagger$ & 0.10 & $*$ \\
\hline \multicolumn{8}{|l|}{$\underline{\text { Job level }}$} \\
\hline Managerial job-level & & 0.09 & 0.03 & 0.03 & 0.03 & 0.03 & \\
\hline Underinvestment (a) & & & $-0,10 \dagger$ & $-0,10 \dagger$ & $-0,11 \dagger$ & $-0,11$ & $\dagger$ \\
\hline Quasi-spot contract (b) & & & $-0,18 * *$ & $-0,18 * *$ & $-0,18 * *$ & $-0,18$ & $* *$ \\
\hline \multicolumn{8}{|l|}{$\underline{\text { Cross-level interaction }}$} \\
\hline LMX X Underinvestment & & & & $-0,05$ & 0.03 & 0.01 & \\
\hline LMX X Quasi-spot contract & & & & 0.07 & 0.10 & 0.08 & \\
\hline \multicolumn{8}{|l|}{$\underline{\text { Mediators }}$} \\
\hline Empowerment & & & & & $0.50 * * *$ & 0.44 & $* * *$ \\
\hline Empowerment X Underinvestment & & & & & & 0.08 & \\
\hline Empowerment X Quasi-spot contract & & & & & & 0.08 & \\
\hline$\underline{\text { Deviance }}$ & 1846 & 1819 & 1737 & 1733 & 1623 & 1623 & \\
\hline
\end{tabular}


Notes.

$* * * \mathrm{p}<0.001 ; * * \mathrm{p}<0.01 ; * \mathrm{p}<0.05 ; \dagger \mathrm{p}<0.10$.

$\mathrm{a} ; \mathrm{b}$ : mutual investment was the referent category. 
Table 3: Staged approach to first and second condition of moderated mediation analysis with emotional exhaustion as outcome

Intercept-

only Model 2B Model 3B Model 4B Model 5B Model 6B

model

\section{Individual level}

Intercept

Gender

Job tenure

LMX

Job level

Managerial job-level

Underinvestment (a)

Quasi-spot contract (b)

Cross-level interaction

LMX X Underinvestment

LMX X Quasi-spot contract

Mediators

Empowerment

Empowerment X Underinvestment

Empowerment X Quasi-spot contract

\begin{tabular}{|c|c|c|c|c|c|c|c|c|c|c|}
\hline \multirow[t]{12}{*}{$2.20 * * *$} & 2.16 & $* * *$ & 2.10 & $* * *$ & 2.08 & $* * *$ & 2.11 & $* * *$ & 2.11 & $* * *$ \\
\hline & 0.08 & & 0.08 & $\dagger$ & 0.08 & $*$ & 0.06 & & 0.06 & \\
\hline & 0.00 & & 0.00 & & 0.00 & & 0.00 & & 0.00 & \\
\hline & & & -0.21 & $* * *$ & -0.21 & $*$ & -0.09 & & -0.07 & \\
\hline & -0.08 & & -0.06 & & -0.06 & & -0.06 & & -0.06 & \\
\hline & & & 0.09 & & 0.10 & & 0.10 & & 0.10 & \\
\hline & & & 0.08 & & 0.09 & & 0.08 & & 0.08 & \\
\hline & & & & & 0.10 & & 0.03 & & 0.00 & \\
\hline & & & & & -0.08 & & -0.10 & & -0.12 & \\
\hline & & & & & & & -0.39 & $* * *$ & -0.46 & $* * *$ \\
\hline & & & & & & & & & 0.13 & \\
\hline & & & & & & & & & 0.07 & \\
\hline
\end{tabular}


Deviance

$\underline{\text { Pseudo } R^{2}}$

Notes.

$* * * \mathrm{p}<0.001 ; * * \mathrm{p}<0.01 ; * \mathrm{p}<0.05 ; \dagger \mathrm{p}<0.10$.

$\mathrm{a} ; \mathrm{b}$ : mutual investment was the referent category.
2067

2038

0.00
1989

0.05
1939

0.09
1939

0.09 
Table 4: Staged approach to third condition of moderated mediation analysis with psychological empowerment as outcome

\begin{tabular}{|c|c|c|c|c|c|c|c|c|c|}
\hline \multirow[b]{2}{*}{ Individual level } & $\begin{array}{l}\text { Intercept- } \\
\text { only model }\end{array}$ & \multicolumn{2}{|c|}{ Model 2} & \multicolumn{2}{|c|}{ Model 3} & \multicolumn{2}{|c|}{ Model 4a } & \multicolumn{2}{|c|}{ Model 4b } \\
\hline & & & & & & & & & \\
\hline Intercept & $3.90 * * *$ & 3.90 & $* * *$ & 3.99 & $* * *$ & 3.99 & $* * *$ & 3.87 & $* * *$ \\
\hline Gender & & -0.06 & $\dagger$ & $-0,06$ & $*$ & $-0,06$ & $*$ & $-0,06$ & $\dagger$ \\
\hline Job tenure & & 0.00 & & 0.00 & & 0.00 & & 0.00 & \\
\hline LMX & & & & 0.22 & $* * *$ & 0.30 & $* * *$ & 0.20 & $* * *$ \\
\hline Job level & & & & & & & & & \\
\hline Managerial job-level & & 0.23 & $* * *$ & 0.17 & $* * *$ & 0.17 & $* * *$ & 0.20 & $* *$ \\
\hline Underinvestment (a) & & & & $-0,06$ & & $-0,06$ & & & \\
\hline Quasi-spot contract (b) & & & & $-0,17$ & $* *$ & $-0,18$ & $* *$ & & \\
\hline Mutual Investment (c) & & & & & & & & 0.12 & $*$ \\
\hline Cross-level interaction & & & & & & & & & \\
\hline LMX X Underinvestment & & & & & & -0.16 & $* * *$ & & \\
\hline LMX X Quasi-spot contract & & & & & & -0.07 & & & \\
\hline LMX X Mutual investment & & & & & & & & 0.10 & $*$ \\
\hline$\underline{\text { Deviance }}$ & 1259 & 1235 & & 1110 & & 1103 & & & \\
\hline Pseudo $R^{2}$ & & 0.04 & & 0.17 & & 0.18 & & & \\
\hline
\end{tabular}


(a; b) Mutual investment as referent category; (c) Underinvestment and quasi-spot contract as referent category.

Models 4 (MI, UI, QS) were tested in order to include coefficients for the simple slopes of the moderation tests. 
Figure 1: Multilevel moderated mediation of the linkage between LMX and affective well-being

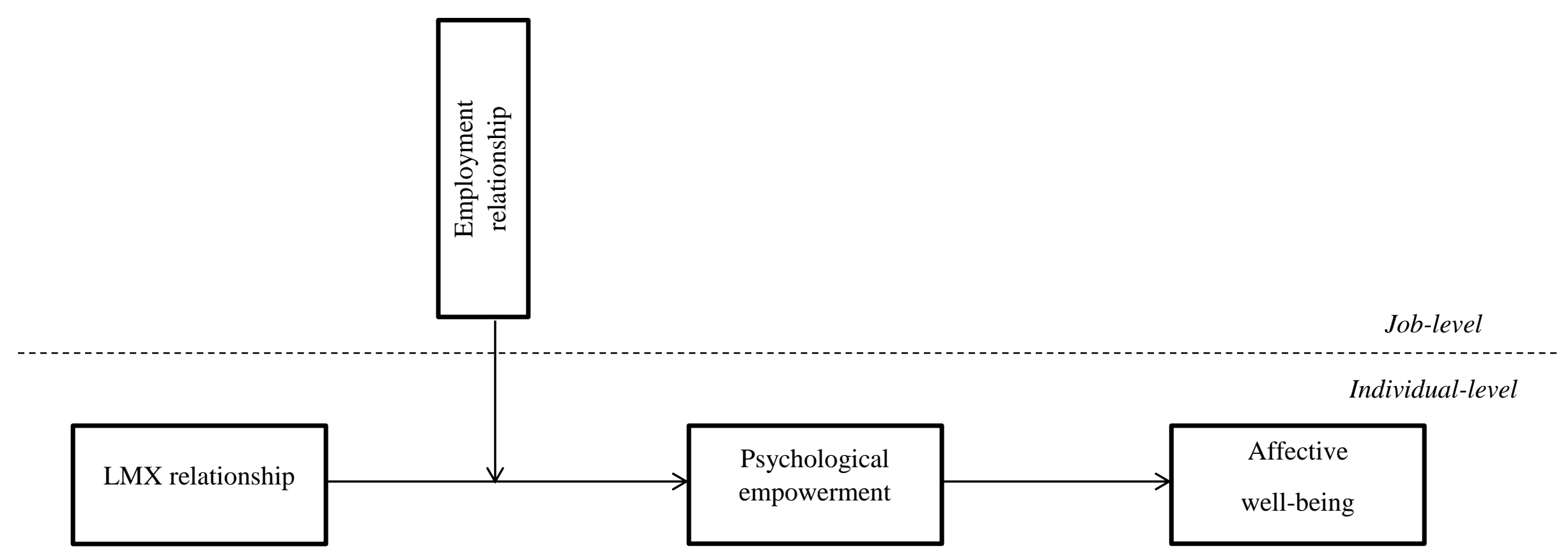


Figure 2: Multilevel moderation of the link between the LMX and psychological empowerment

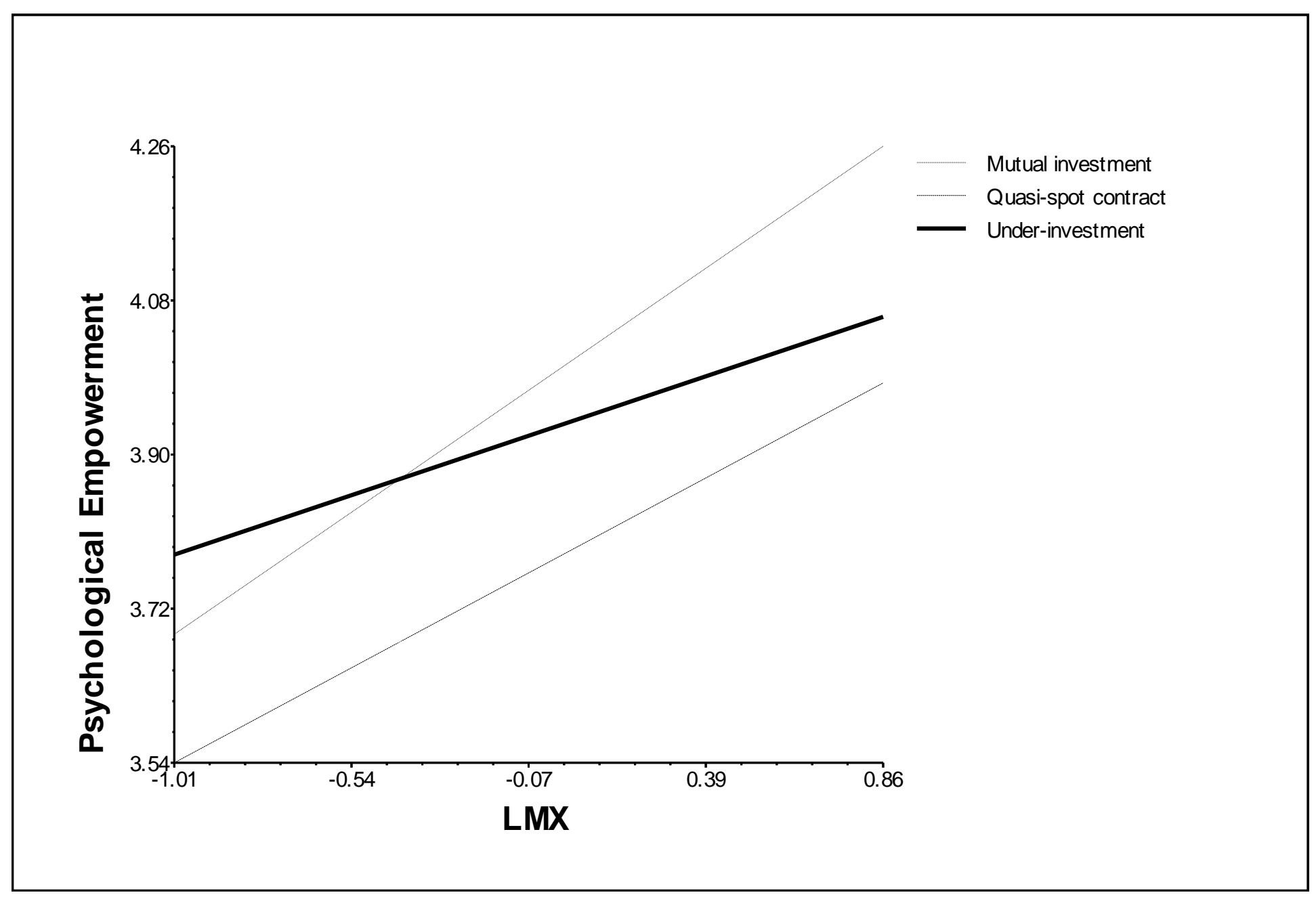

